\title{
Western Blotting Using Strongyloides ratti Antigen for the Detection of IgG Antibodies as Confirmatory Test in Human Strongyloidiasis
}

\author{
Luciana Pereira Silva ${ }^{++}$, Ivanildes Solange da Costa Barcelos, Andréia Barcelos Passos- \\ Lima*, Foued Salmen Espindola*, Dulcinéa Maria Barbosa Campos**, \\ Julia Maria Costa-Cruz ${ }^{+}$
}

\begin{abstract}
Departamento de Imunologia, Microbiologia e Parasitologia, Instituto de Ciências Biomédicas *Instituto de Genética e Bioquímica, Universidade Federal de Uberlândia, Av. Pará 1720, 38400-902 Uberlândia, MG, Brasil **Departamento de Parasitologia, Instituto de Patologia Tropical e Saúde Pública, Universidade Federal de Goiás, Goiânia, GO, Brasil
\end{abstract}

The present study was conducted to evaluate the frequency of antigenic components recognized by serum $\operatorname{Ig} G$ antibodies in Western blotting (WB) using a Strongyloides ratti larval extract for the diagnosis of human strongyloidiasis. In addition, the WB results were compared to the enzyme-linked immunosorbent assay (ELISA) and the indirect immunofluorescence antibody test (IFAT) results. Serum samples of 180 individuals were analyzed (80 with strongyloidiasis, 60 with other intestinal parasitoses, and 40 healthy individuals). S. ratti was obtained from fecal culture of experimentally infected Rattus rattus. For IFAT, S. ratti larvae were used as antigen and S. ratti larval antigenic extracts were employed in WB and ELISA. Eleven S. ratti antigenic components were predominantly recognized by $\operatorname{Ig} G$ antibodies in sera of patients with strongyloidiasis. There was a positive concordance for the three tests in $87.5 \%$ of the cases of strongyloidiasis. The negative concordance in the three tests was $94 \%$ and $97.5 \%$, in patients with other intestinal parasitoses and healthy individuals, respectively. In cases of positive ELISA and negative IFAT results, diagnosis could be confirmed by WB. ELISA, IFAT, and WB using S. ratti antigens showed a high rate of sensitivity and specificity. In conclusion, WB using S. ratti larval extract was able to recognize 11 immunodominant antigenic components, showing to be a useful tool to define the diagnosis in cases of equivocal serology.

Key words: Strongyloides stercoralis - Strongyloides ratti - strongyloidiasis - immunodiagnosis - Western blotting

Strongyloidiasis, caused by the nematode Strongyloides stercoralis, is one of the major intestinal infections in humans and is distributed worldwide in both tropical and temperate countries (Grove 1996). In Brazil the infection rates vary according to the region. Uberlândia, a city located in the Southeastern region, state of Minas Gerais, was considered as hyperendemic area for $S$. stercoralis by Machado and Costa-Cruz (1998) through parasitological findings demonstrating that $13 \%$ of the children were infected. Considering the severity of this disease in immunocompromised patients, Ferreira et al. (1999) described 25 cases of $S$. stercoralis and human immunodeficiency virus (HIV) infections in patients followed up in School Hospital, including seven cases of hyperinfection syndrome, which were further confirmed in autopsy through dissemination to various organs.

Financial support: Conselho Nacional de Desenvolvimento Científico e Tecnológico, and Fundação de Amparo à Pesquisa do Estado de Minas Gerais, Brasil

${ }^{+}$Corresponding author. Fax: +55-34-3218.2333. E-mail: costacruz@ufu.br

${ }^{++}$Graduate student of Applied Immunology and Parasitology, Federal University of Uberlândia, MG, Brazil.

Received 30 October 2002

Accepted 5 June 2003
One of the current problems concerning strongyloidiasis is the difficulty to detect larvae in human feces, because the majority of cases involve chronic, low-level infection, and the larval output is minimal and irregular. Although the agar plate method for stool culture appears to be more sensitive than common parasitological methods, it is more time consuming (Arakaki et al. 1990, Sato et al. 1995, Dreyer et al. 1996, Uparanukraw et al. 1999).

Detection of parasite-specific antibodies by indirect immunofluorescence antibody test (IFAT) and enzymelinked immunosorbent assay (ELISA) may be a useful complement to the parasitological diagnosis of strongyloidiasis (Conway et al. 1993a, Costa-Cruz et al. 1997, De Paula et al. 2000), but such tests show cross-reactivity with filaria, schistosomes, hookworm, Ascaris lumbricoides, Trichuris trichiura and Echinococcus (Gam et al. 1987, Conway et al. 1993a,b, Lindo et al. 1994). Western blotting (WB) tests have been applied with more specificity in the immunodiagnosis of strongyloidiasis (Genta et al. 1988, Sato et al. 1990, Conway et al. 1994, Atkins et al. 1999, Uparanukraw et al. 1999). It should be emphasized that the presence of chronic strongyloidiasis infections is often very difficult to rule out. Therefore a positive serologic test in someone parasitologically negative may still be a true positive.

Several components of $S$. stercoralis filariform larvae are recognized by antibodies in sera of infected humans, including surface and excretory-secretory proteins (Brindley et al. 1988, 1995, McKerrow et al. 1990). 
Studies on the antigenic composition of extracts from $S$. ratti and $S$. venezuelensis compared to those of $S$. stercoralis suggest that these rodent species might be used as antigen sources for the immunodiagnosis of human strongyloidiasis instead of $S$. stercoralis antigens (Sato et al. 1995). The purpose of this study was to evaluate the frequency of antigenic components recognized by serum IgG antibodies in WB using S. ratti larval antigenic extract for the diagnosis of human strongyloidiasis. In addition, the WB results were compared to the ELISA and the IFAT results.

\section{MATERIALS AND METHODS}

Patients and serum samples - Serum samples of 180 individuals were analyzed, from which 80 were from patients who were shedding $S$. stercoralis larvae only in the feces; 60 from patients with other intestinal parasitoses (hookworm, 20 cases; Ascaris lumbricoides, 7 cases; Enterobius vermicularis, 7 cases; Hymenolepis nana, 9 cases; Trichuris trichiura, 6 cases; Schistosoma mansoni, 6 cases; Giardia lamblia, 5 cases), all from the Clinical Hospital, Federal University of Uberlândia, state of Minas Gerais, Brazil; and 40 serum samples of University students with parasitological analysis negative in three fecal samples (Baermann 1917, Lutz 1919, and Moraes 1948 methods) and with no history of Strongyloides infection. Serum from a patient who presented S. stercoralis larvae in the feces was used as positive control and three sera from healthy individuals (negative in three fecal samples) were used as negative controls. This study received approval from the Ethical Committee of the Federal University of Uberlândia.

Parasites - S. ratti larvae were obtained from the feces of experimentally infected rats (Rattus rattus). The fecal samples were mixed with an equal part of finely ground wood charcoal, moistened with water, spread equally on Petri dishes and incubated at $25^{\circ} \mathrm{C}$ for 5 days. Filariform larvae were then harvested according to the Baermann (1917)-Moraes (1948) method, concentrated by centrifugation for $5 \mathrm{~min}$ at $1000 \mathrm{~g}$ and stored at $-20^{\circ} \mathrm{C}$ until being processed.

Antigens - For WB and ELISA, the larval extracts were obtained from 288000 filariform larvae, resuspended in $1 \mathrm{ml}$ of phosphate buffered saline (PBS) $\mathrm{pH} 7.2$ containing protease inhibitors ( $1 \mathrm{mM} \mathrm{EGTA,} 10 \mathrm{mM}$ EDTA, and 0.05 mM PMSF), and sonicated on ice ( 8 cycles of $20 \mathrm{~s}$ ). The larval suspension was then centrifuged at $13000 \mathrm{~g}$ for 30 $\min$ at $4^{\circ} \mathrm{C}$, and the supernatant (larval extract) was submitted to protein estimation by the Lowry et al. (1951) method. For IFAT, S. ratti antigens were prepared according to Costa-Cruz et al. (1997).

Rabbit immune gammaglobulin - Immune serum from a rabbit experimentally infected with $S$. ratti filariform larvae on successive inoculations was submitted to salt precipitation (3.12 M amonium sulfate, $\mathrm{pH} 6.5$ ) to obtain the gammaglobulin fraction. After incubation for $18 \mathrm{~h}$ at $4^{\circ} \mathrm{C}$ the preparation was centrifuged at $3000 \mathrm{~g}$ for $30 \mathrm{~min}$ at $4^{\circ} \mathrm{C}$. The pellet was washed three times in $1.56 \mathrm{M}$ amonium sulfate $\mathrm{pH} 6.5$ and dialyzed for $24 \mathrm{~h}$ at $4^{\circ} \mathrm{C}$ against saline solution. Normal rabbit gammaglobulin was used as negative control.
Electrophoresis and electrophoretic transfer - Larval extract of the parasite was diluted (v/v) in sample buffer ( $6.5 \mu \mathrm{g}$ of final protein content), boiled for $3 \mathrm{~min}$ at $100^{\circ} \mathrm{C}$, and submitted to sodium dodecyl sulfate-polyacrylamide gel electrophoresis (SDS-PAGE) using a $12 \%$ resolving gel under denaturant and reducing conditions (Biorad System, US), as described by Laemmli (1970). After SDSPAGE, the gels were either stained by Coomassie brilliant blue or transferred to nitrocellulose membranes $(0.45 \mu \mathrm{m}$; Sigma, US), as described by Towbin et al. (1979), using a transfer apparatus (Hoefer System, US).

Serological assays

$W B-\operatorname{Ig} G$ - Nitrocellulose strips ( $4 \mathrm{~mm}$ wide) were blocked with 5\% non-fat milk in PBS containing 0.05\% Tween 20 (PBS-T) for $2 \mathrm{~h}$ at room temperature and subsequently incubated overnight at $4{ }^{\circ} \mathrm{C}$ with rabbit or human serum samples diluted at 1:40 in 1\% non-fat milk in PBS-T (PBSTM). After washing in PBSTM, the strips were incubated for $2 \mathrm{~h}$ at room temperature with the conjugate (antihuman $\mathrm{IgG}$, whole molecule, labeled with peroxidase, Sigma) diluted at 1:200 in PBSTM. The strips were washed in PBS and developed with hydrogen peroxide and 3,3' diaminobenzidine tetrahydrochloride (DAB-Sigma) for 3 $\min$. The strips were washed with distilled water and the positive reactions were determined by the visualization of clearly defined brown bands. The apparent molecular weight of such bands were estimated in comparison with the linear regression curve obtained from the electrophoretic relative mobility (Rf) versus the molecular masses of the markers (Rainbow ${ }^{\mathrm{tm}}$; Amersham, England): myosin $(220 \mathrm{kDa})$, phosphorilase b $(97.4 \mathrm{kDa})$, bovine serum albumin (66 kDa), ovalbumin (46 kDa), carbonic anhydrase $(30 \mathrm{kDa})$, trypsin inhibitor $(21.5 \mathrm{kDa})$ and lysosyme $(14.3 \mathrm{kDa})$.

ELISA-IgG - Preliminary experiments were carried out in order to determine the optimal conditions for ELISAIgG, through block titration of the reagents (antigen, sera, and conjugate). ELISA was carried out in polystyrene microplates (Interlab, São Paulo, Brazil) and immunoreagents were assayed in $50 \mu \mathrm{l} /$ well. After each step of the reaction, microplates were washed three times for 5 min with PBS-T. Microplate coating was performed diluting the larval extract at $0.5 \mu \mathrm{g} / \mathrm{well}$ in $0.06 \mathrm{M}$ carbonatebicarbonate buffer, $\mathrm{pH} 9.6$ and incubating overnight at $4^{\circ} \mathrm{C}$. The microplates were washed and incubated with the serum samples diluted at 1:40 in PBS-T for $45 \mathrm{~min}$ at $37^{\circ} \mathrm{C}$. The conjugate, goat IgG anti-human IgG (Fc chain) labeled with peroxidase (Sigma), was diluted at 1:2000 in PBS-T and incubated for $45 \mathrm{~min}$ at $37^{\circ} \mathrm{C}$. The enzymatic substrate consisted of $\mathrm{H}_{2} \mathrm{O}_{2}$ plus o-phenylenodiamine (OPD) solution in $0.1 \mathrm{M}$ citrate- $\mathrm{Na}_{2} \mathrm{HPO}_{4}$ buffer, $\mathrm{pH}$ 5.5. The reaction was stopped after $15 \mathrm{~min}$ with $25 \mu \mathrm{l} /$ well of 1 $\mathrm{M} \mathrm{H}_{2} \mathrm{SO}_{4}$ and the absorbance was determined in an ELISA reader (Metrolab, Argentine) at $490 \mathrm{~nm}$. The cut off was established using the mean absorbance of five nonreactive serum samples plus two standard deviations, as described by Bassi et al. (1991). Reactive serum samples were retested in two-fold serial dilutions until the endpoint titer.

IFAT-IgG - The immunofluorescence test using S. ratti 
antigen was carried out according to Costa-Cruz et al. (1997). Briefly, S. ratti filariform larvae were embedded in Tissue Tek ${ }^{\circledR}$ (O.C.T. compound, Miles) and cut into $4 \mu$ sections with a cryo-microtome (Cryocut 1800 ReichertJung). The sections were put onto extra-thin slides (76 $\mathrm{mm} \times 76 \mathrm{~mm}$ ) previously cleaned in an alcohol-ether solution, then dried at room temperature and preserved at $-18^{\circ} \mathrm{C}$ up to the time of use. Both negative and positive control sera, as well as the test samples, were diluted 1:20 in PBS and added on the slides containing larval antigens. The positive sera were further retested in 2 -fold serial dilutions. After incubation for $30 \mathrm{~min}$ at $37^{\circ} \mathrm{C}$ the slides were washed three times in PBS for $5 \mathrm{~min}$ and the fluoresceinated anti-human IgG conjugate (Biolab, Brazil) was added at 1:100 in PBS containing 1\% Evans blue as contrast stain. After $30 \mathrm{~min}$ incubation at $37^{\circ} \mathrm{C}$ the slides were washed again as described above, mounted in glycerin ( $\mathrm{pH} 8.5$ ) and examined in an Olympus BH 2 RFC immunofluorescence microscope at 200 and 400X. Results were expressed in titers, which were considered positive when $\geq 20$. Reactive serum samples were retested in twofold serial dilutions until the end-point titer.

Statistical analysis - Statistical analysis was performed using the Statistics for Windows software (Stat soft Inc, 1993). The frequencies of antigenic components recognized by IgG antibodies in WB among the different groups were compared using the analysis between two proportions by Z statistics. Differences were considered statistically significant at level of $5 \%$.

\section{RESULTS}

Sera were obtained from 85 men and 95 women. In patients with strongyloidiasis, patients' ages ranged from 4 to 80 years $(y r)$ old $(36.9 \pm 16.5 \mathrm{yr})$ and in control groups (patients with other intestinal parasitoses and healthy individuals), patients' ages ranged 1 to 70 years old (21.6 $\pm 12.8 \mathrm{yr})$.

Thirty-five antigenic components (apparent molecular weight of $8,10,14,17,20,23,26,28-35,37,40,44,46,48$, $52,55,60,66,70,75,78,81,85,89,90,91,97,105,113,117$, $122,126,132,138,141$ and $148 \mathrm{kDa}$ ) were recognized by IgG antibodies in WB using $S$. ratti larval extract in 180 serum samples. Infection-specific immunodominant antigenic components were defined as the ones recognized by at least $25 \%$ of strongyloidiasis patients. Thus, $11 \mathrm{im}-$ munodominant antigenic components $(10,14,17,20,26$, $28-35,55,81,85,126$ and $138 \mathrm{kDa})$ were significantly more frequent $(p<0.05)$ in patients with strongyloidiasis as compared to patients with other intestinal parasitoses and healthy individuals (Fig. 1). A representative WB using S. ratti larval extract is illustrated in Fig. 2. The criteria for positivity in WB were established as reaction with two or more of the infection-specific immunodominant antigenic components.

The rabbit immune serum recognized 14 antigenic fractions that were coincident with those recognized by serum samples from patients with strongyloidiasis or other parasitoses and healthy individuals. The rabbit normal serum reacted with the bands of $52 \mathrm{kDa}$ and $148 \mathrm{kDa}$, similarly to those recognized by serum samples of healthy individuals.

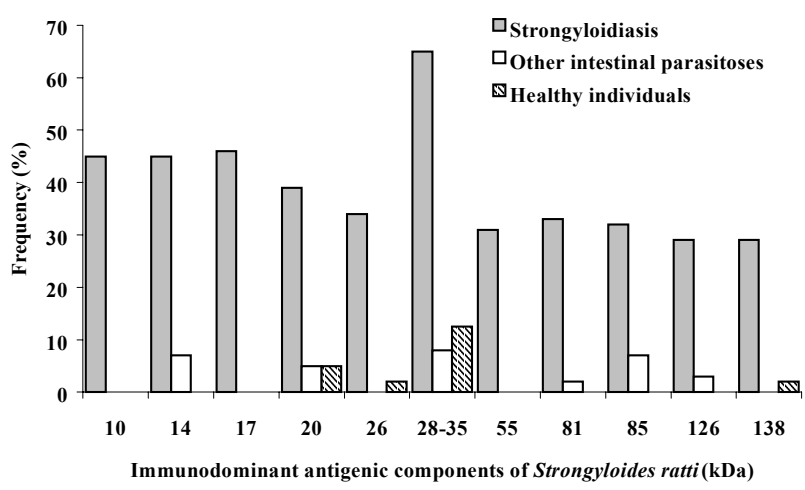

Fig. 1: frequency of 11 immunodominant antigenic components of Strongyloides ratti recognized by IgG antibodies in 180 serum samples (80 patients with strongyloidiasis, 60 patients with other intestinal parasitoses, and 40 healthy individuals) in Western blotting for the diagnosis of human strongyloidiasis.

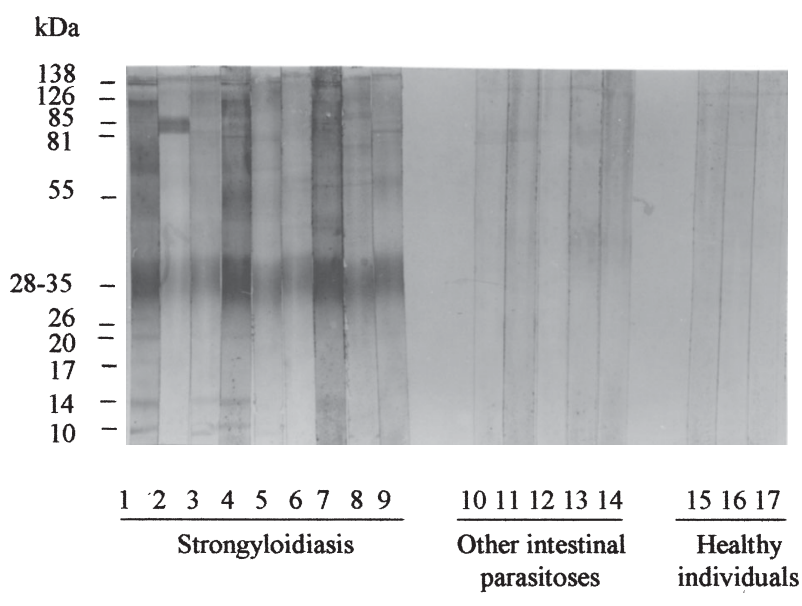

Fig. 2: Western blotting for the detection of IgG antibodies in serum samples (1:40 dilution). Strongyloides ratti larval extract was submitted to SDS-PAGE at $12 \%$. Lanes show serum samples from patients with strongyloidiasis (1 to 9), patients with other intestinal parasitoses (10 to 14), and healthy individuals (15 to 17 ).

Antibody titers in ELISA ranged from 40 to 320 and IFAT titers ranged from 20 to 2560 .

WB, ELISA and IFAT showed sensitivity of $96 \%, 100 \%$ and $90 \%$, respectively, whereas specificity values were $96 \%, 98 \%$, and $100 \%$, respectively. Sensitivity was found to be significantly different between WB and ELISA, WB and IFAT, and ELISA and IFAT $(\mathrm{p}<0.05)$. In contrast, specificity showed no statistically significant difference among the three tests $(p>0.05)$. Comparison between sensitivity and specificity values demonstrated statistically significant differences between the tests $(p<0.05)$.

Fig. 3 shows the comparison of positivity rates among the three tests (WB, ELISA and IFAT) for the detection of IgG antibodies anti-S. ratti in serum samples of patients with strongyloidiasis or other parasitoses and healthy individuals. There was $87.5 \%$ positive concordance and $12.5 \%$ discordance $(9 \%$ for $\mathrm{WB}+/$ ELISA+/IFAT-, $1 \%$ for WB-/ELISA+/IFAT- and $2.5 \%$ for WB-/ELISA+/IFAT + ) in the group of patients with strongyloidiasis. Sera of patients with other intestinal parasitoses showed 93\% 


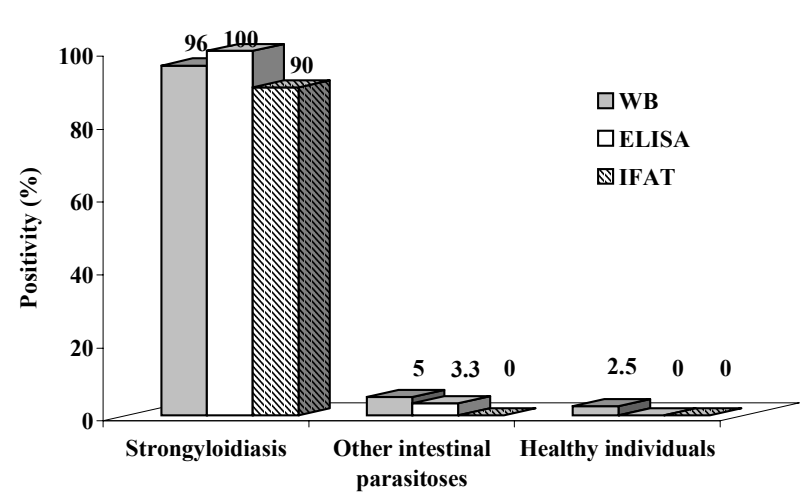

Fig. 3: comparison between positivity percentages obtained in Western blotting (WB), enzyme-linked immunosorbent assay (ELISA) and the indirect immunofluorescence antibody test (IFAT) for the detection of IgG antibodies using Strongyloides ratti larval extract in serum samples from 80 patients with strongyloidiasis, 60 patients with other parasitoses, and 40 healthy individuals.

negative concordance and $7 \%$ discordance $(3.5 \%$ for WB+/ELISA+/IFAT- and 3.5\% for WB+/ELISA-/IFAT-). Sera of healthy individuals showed $97.5 \%$ negative concordance and 2.5\% discordance (WB+/ELISA-/IFAT-).

\section{DISCUSSION}

S. ratti larval extract was studied for the diagnosis of human strongyloidiasis in three tests: WB, ELISA and IFAT. These tests demonstrated sensitivity and specificity values equal or higher than $90 \%$, showing statistically significant differences only with respect to sensitivity, being ELISA the most sensitive test, followed by WB and IFAT.

S. ratti larvae provide convenient antigens for the immunodiagnosis of strongyloidiasis, mainly because the logistics of antigen preparation would be greatly simplified, since keeping rats infected with $S$. ratti would be much easier than maintaining immunosuppressed monkeys with $S$. stercoralis with relatively easy mass production of filariform larvae. Therefore, $S$. ratti larvae can be an adequate substitute antigen of $S$. stercoralis using ELISA and IFAT (Grove \& Blair 1981, Sato et al. 1995, Costa-Cruz et al. 1997). The WB test was used for the first time in this study and showed immunodominant antigenic components of $S$. ratti larval extract. However, these results should be considered as a first approach for this issue, since further studies are required to compare the immunodominant antigenic components from the studied species (S. ratti) to those from S. stercoralis. In addition, the use of purified antigens obtained by detergent extraction should be also tested rather than the crude antigenic extract.

In the present work, 35 antigenic components were recognized in WB by serum samples of patients with strongyloidiasis or other intestinal parasitoses and healthy individuals. From these, 11 immunodominant antigenic components $(10,14,17,20,26,28-35,55,81,85,126$ and $138 \mathrm{kDa}$ ) were predominantly recognized by infected human sera.

In this study, immunodominant $S$. ratti antigenic com- ponents with apparent molecular weight of 10, 14, 126 and $138 \mathrm{kDa}$ were reported for the first time in the diagnosis of human strongyloidiasis, and these bands were also recognized by rabbit immune sera. Other investigations have employed S. stercoralis larval extract in WB (Genta et al. 1988, Sato et al. 1990, Atkins et al. 1999).

S. stercoralis immunodominant antigenic components with apparent molecular weigth of 28,31 and $41 \mathrm{kDa}$ were identified as useful antigens for specific immunodiagnosis of strongyloidiasis in serum samples (Conway et al. 1993b, Lindo et al. 1994, Uparanukraw et al. 1999). In the present study, using S. ratti antigen, we also verified the importance of these two first components ( 28 and $31 \mathrm{kDa}$ ) by visualization of a smear of $28-35 \mathrm{kDa}$, as the most frequent band $(65 \%)$. However the $S$. ratti larval antigen apparently does not have a $41 \mathrm{kDa}$, thus evidencing a difference between S. stercoralis and S. ratti antigen. Accordingly, using S. cebus and S. ratti, Conway et al. (1994) reported recognition of antigenic bands with apparent molecular masses of 28, 31 and $41 \mathrm{kDa}$ in the $S$. stercoralis extract only.

Several proteins on the surface of S. stercoralis filariform larvae, including one of $30 \mathrm{kDa}$, and several excretory-secretory larval products, including those of 40, 30 and $25 \mathrm{kDa}$, were identified by Brindley et al. (1988) and recognized by antibodies from infected patients. Similar sized bands were seen in this study, in which the range $28-35 \mathrm{kDa}$ showed the higher positivity. The $25 \mathrm{kDa}$ protein may correspond to the $26 \mathrm{kDa}$ band described here.

Cases with strongyloidiasis showed $87.5 \%$ positive concordance in the three tests and $93 \%$ and $97.5 \%$ negative concordance in the three tests, respectively, for patients with other intestinal parasitoses and healthy individuals. These data reinforce the necessity to perform immunological tests that could confirm the diagnosis and avoid false-positive results. In cases of positive ELISA and negative IFAT, WB could define the diagnosis in eight cases $(10 \%)$ of patients with strongyloidiasis and two cases $(3.5 \%)$ of patients with other intestinal parasitoses, suggesting that WB may be a useful confirmatory test.

Cross-reactivity occurred with hookworm (1 case) and T. trichura (1 case) for both positive WB and ELISA. However, our region is located more than $2500 \mathrm{~km}$ far from the endemic area for filariasis in our country, the latter situated in the Northeastern region. Thus, data about specificity should be restricted to non-endemic areas of filariasis because of the known cross-reactivity (Dreyer et al. 1996).

In conclusion, WB, ELISA and IFAT showed a high rate of sensitivity and specificity in the detection of serum IgG using $S$. ratti antigen in human strongyloidiasis. In addition, $\mathrm{WB}$ was able to recognize 11 immunodominant antigenic components of $S$. ratti, showing to be a useful tool to define the diagnosis in cases of equivocal serology.

\section{REFERENCES}

Arakaki T, Iwanaga M, Kinjo F, Saito A, Asato R, IkeshiroT 1990. Efficacy of agar-plate culture in detection of Strongyloides stercoralis infection. J Parasitol 76: 425-428.

Atkins NS, Conway DJ, Lindo JF, Bailey JW, Bundy DPA 
1999. L3 antigen-specific antibody isotype responses in human strongyloidiasis: correlations with larval output. Parasite Immunol 21: 517-526.

Baermann G 1917. Eine Einfache Methode zur Auffindung von Ankylostomum (Nematoden) Larven in Erdproben, Mededeel. mit h. Geneesk, Lab Weltvreden Feestbundel, Batavia, p. 41-47.

Bassi GE, Ishiki DK, Ferreira AW, Camargo ME 1991. A reação imunoenzimática para cisticercose no líquido cefalorraquidiano - Considerações sobre o limiar de reatividade. Rev Bras Pat Clin 27: 49-52.

Brindley PJ, Gam AA, McKerrow JH, Neva FA 1995. Ss40: the zinc endopeptidase secreted by infective larvae of Strongyloides stercoralis. Exp Parasitol 80: 1-7.

Brindley PJ, Gam AA, Pearce J, Poindexter RW, Neva FA 1988. Antigens from the surface and excretion/secretions of the filariform larvae of Strongyloides stercoralis. Mol Biochem Parasitol 28: 171-180.

Conway DJ, Atkins NS, Lillywhite JE, Bailey JW, Robinson RD, Lindo JF, Bundy DAP, Bianco AE 1993a. Immunodiagnosis of Strongyloides stercoralis infection: a method for increasing the specificity of the indirect-ELISA. Trans R Soc Trop Med Hyg 87: 173-176.

Conway DJ, Bailey JW, Lindo JF, Robinson RD, Bundy DAP, Bianco AE 1993b. Serum IgG reactivity with 41-, 31-, and $28-\mathrm{kDa}$ larval proteins of Strongyloides stercoralis in individuals with strongyloidiasis. J Infect Dis 168: 784-787.

Conway DJ, Lindo JF, Robinson RD, Bundy DAP, Bianco AE 1994. Strongyloides stercoralis: characterization of immunodiagnostic larval antigens. Exp Parasitol 79: 99-105.

Costa-Cruz JM, Bullamah CB, Gonçalves-Pires MRF, Campos DMB, Vieira MA 1997. Cryo-microtome sections of coproculture larvae of Strongyloides stercoralis and Strongyloides ratti as antigen sources for the immunodiagnosis of human strongyloidiasis. Rev Inst Med Trop São Paulo 39: 313-317.

De Paula FM, Castro E, Gonçalves-Pires MRF, Marçal MG, Campos DMB, Costa-Cruz JM 2000. Parasitological and immunological diagnoses of strongyloidiasis in immunocompromised and non-immunocompromised children at Uberlândia, State of Minas Gerais, Brazil. Rev Inst Med Trop São Paulo 42: 51-55.

Dreyer G, Fernandes-Silva E, Alves S, Rocha A, Albuquerque R, Addiss D 1996. Patterns of detection of Strongyloides stercoralis in stool specimens: implications for diagnosis and clinical trials. J Clin Microbiol 34: 2569-2571.

Ferreira MS, Nishioka SA, Borges AS, Costa-Cruz JM, Rossin IR, Rocha A, Silvestre MTA, Nunes-Araújo FRF 1999. Strongyloidiasis and infection due to human immunodeficiency virus: 25 cases at a Brazilian teaching hospital, including seven cases of hyperinfection syndrome. Clin Inf
Dis 28: 154-155.

Gam AA, Neva FA, Krotoski WA 1987. Comparative sensitivity and specificity of ELISA and IHA for serodiagnosis of strongyloidiasis with larval antigens. Am J Trop Med Hyg 37: 157-161.

Genta RM, Gatti S, Linke MJ, Cevini C, Scaglia M 1988. Endemic strongyloidiasis in northern Italy: clinical and immunological aspects. Quart J Med 68: 679-690.

Grove DI 1996. Human strongyloidiasis. Adv Parasitol 38: 251-309.

Grove DI, Blair AJ 1981. Diagnosis of human strongyloidiasis by immunofluorescence, using Strongyloides ratti and $S$. stercoralis larvae. Am J Trop Med Hyg 30: 344-349.

Laemmli UK 1970. Cleavage of structural proteins during the assembly of the head of bacteriophage T4. Nature 227: 680-685.

Lindo JF, Conway DJ, Atkins NS, Bianco AE, Robinson RD, Bundy DAP 1994. Prospective evaluation of enzyme-linked immunosorbent assay and immunoblot methods for the diagnosis of endemic Strongyloides stercoralis infection. Am J Trop Med Hyg 51: 175-179.

Lowry OH, Rosebrough NJ, Farr AL, Randall RJ 1951. Protein measurement with the folin phenol reagent. J Biol Chem 29: 265-275.

Lutz AV 1919. Schistosoma mansoni e a schistosomose, segundo observações feitas no Brasil. Mem Inst Oswaldo Cruz 11: 121-125.

Machado ER, Costa-Cruz JM 1998. Strongyloides stercoralis and other enteroparasites in children at Uberlândia city, state of Minas Gerais, Brazil. Mem Inst Oswaldo Cruz 93: 161-164.

McKerrow JH, Brindley P, Brown M, Gam AA, Staunton C, Neva FA 1990. Strongyloides stercoralis: identification of a protease that facilitates penetration of skin by the infective larvae. Exp Parasitol 70: 134-143.

Moraes RG 1948. Contribuição para o estudo do Strongyloides stercoralis e da estrongiloidíase no Brasil. Rev Serv Esp Saúde Pública 1: 507-624.

Sato Y, Inoue F, Matsuyama R, Shiroma Y 1990. Immunoblot analysis of antibodies in human strongyloidiasis. Trans $R$ Soc Trop Med Hyg 84: 403-406.

Sato Y, Kobayashi J, Shiroma Y 1995. Serodiagnosis of strongyloidiasis. The application and significance. Rev Inst Med Trop São Paulo 37: 35-41.

Towbin H, Staehelin T, Gordon J 1979. Electrophoretic transfer of proteins from polyacrylamide gels to nitrocellulose sheets: procedure and some applications. Proc Natl Acad Sci 76: 4350-4354.

Uparanukraw P, Phongsri S, Morakote N 1999. Fluctuations of larval excretion in Strongyloides stercoralis infection. Am J Trop Med Hyg 60: 967-973. 